\title{
Compressive Strength of Concrete with Construction and Demolition Waste and m-SAND using Additives
}

\author{
DivyaSrinath, Shashishankar A, Ravindra R, Mohiyuddin C S
}

\begin{abstract}
Construction and Demolition wastes(C\&D wastes) are generated in all cities of the world due to rapid urbanization. Disposing $C \& D$ waste these days is a costly affair, and raises environmental issues. Hence an attempt is made to reuse the demolished concrete as a partial replacement of natural coarse aggregates. Also due to ban of sand mining by local authorities, the cost of natural fine aggregate is very high and itself becoming a scarce material. Hence crushed stone aggregates called manufactured sand ( $m$ sand) is used, totally replacing natural fine aggregates. This concept is found to be cost effective, minimizes disposal of $C \& D$ wastes, and leads towards Green Building Concepts.

Compression test on M40 concrete cubes of size $150 \mathrm{~mm} x 150 \mathrm{~mm} \times 150 \mathrm{~mm}$ are conducted at end of 7 days and 28days. Mix design for M40 concrete is made in accordance to IS: 10262-2019 with water cement ratio of 0.45 using 53 Grade Ordinary Portland cement. Superplasticizer (LIQUIFIX) is used to enhance workability. Nano Silica (NS)(1.5\% by weight of cement), Wollastonite powder(WP)(10\%by weight of cement) and Basalt fibres $(B F)(1 \%$ by weight of cement) are added as additives.

It is observed, that compressive strength of 7 days and 28 days cured samples is $25 \%$ more with the addition of all three additives compared to samples without additives. Hence the loss of compressive strength obtained by using demolished concrete as aggregates and $m$ sand in concrete is regained with the addition of additives.
\end{abstract}

Index Terms-Construction \& Demolition waste, Concrete, m Sand, Nano Silica, Basalt fibres, Wollastonite powder.

\section{INTRODUCTION}

Globally, Construction \& demolition waste is generated every year of the order 2.2 Billion tons per annum and in India it is 10 to 12 million tons per annum, as per the statistics available. Disposing this waste is a very costly affair, and disposing by filling in open grounds, will lead to health problems of the public and raises environmental issues. Hence an attempt is made to reutilize the demolished concrete in concrete, to evaluate its compressive strength,

Revised Manuscript Received on July 22, 2019.

Divya Srinath, Associate Professor, Department of Civil Engineering,Nagarjuna College of Engineering and Technology, Bangalore.

Shashishankar A, Professor, Department of Civil Engineering, AMC College of Engineering, Bangalore.

Ravindra R, Associate Professor, Department of Civil Engineering, Rashtreeya Vidyalaya College of Engineering, Bangalore

Mohiyuddin C S, Assistant Professor, Department of Civil Engineering, AMC College of Engineering, Bangalore. after 7 days and 28 days curing. After assessing the compressive strength at end of 7 day and 28 days, the outcome of the work will enable its applicability of its use in structural elements. Research works carried out by various authors involve Compressive Strength Tests, Flexural Tests, Split Tensile Tests, and Durability Tests, indicate the following facts: Forood Torabian Isfahani et al.[1], mentions that there was a remarkable improvement of compressive strength of $41 \%$, by using Nano silica. Rutuja Mininath Sarade et al.[2], concludes that by adding Nano silica , it reduces carbon dioxide emission and also $20 \%$ increase in compressive strength is observed. Renu Mathur et al.[3] in their work states that with the addition of Wollastonite powder, an $28 \%$ to $35 \%$ increase in compressive strength and an $36 \%$ to $42 \%$ increase in flexural strength, were observed. Also, reduction in water absorption, drying shrinkage, abrasion loss of concrete, enhancement of durability against sulphate attack and alternate freezing \& thawing were observed. Kandula Mohan Krishna Reddy et al.[4] observed an $24 \%$ increase in compressive strength , and $14 \%$ increase in flexural strength with addition of Wollastonite powder. Tehmina Ayub et al.[5] in his work indicates that with the addition of Basalt fibres the compressive strength, tensile splitting strength and the flexural strength of concrete increased significantly. Nayan Rathod et al.[6] concludes that use of Basalt fibres in concrete has multifold benefits. The benefits of using Basalt fibres are: it is non corrosive, the flexural and compressive strengths increases, and has good thermal resistivity.

\section{METHODOLOGY}

As per the IS 10262:2019, for M40 Grade concrete, the proportions by weight of cement/Fine aggregate/coarse aggregate 1:2.56:3.26 is followed, six concrete cubes are cast for Normal Concrete, another six cubes are cast with demolished concrete $50 \%$ replacement for natural coarse aggregates), and with $\mathrm{m}$ sand (100\% replacement for natural fine aggregate), and another six cubes with demolished concrete and $\mathrm{m}$ sand with additives Nano silica(1.5\% by weight of cement, Basalt fibres (1\% by weight of cement and Wollastonite powder( $10 \%$ by weight of cement) as additives are cast. The percentages of additives are the optimum percentage obtained by experimental tests on compressive strength of cubes tried individually with each additive. Tables 2 to 4 gives the details of optimal percentages of Nano Silica, Basalt fibres and Wollastonite powder.

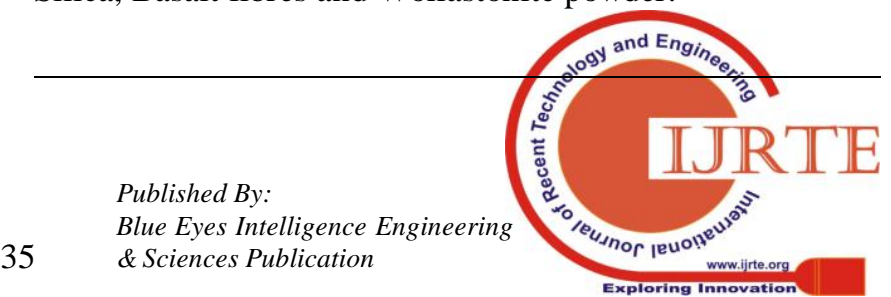


After 7 days and 28 days of curing the cubes are tested for compressive strength. Table. 1 to $4 \&$ Fig. 1 to 4 shows the comparison of the experimental results obtained for compressive strength.

\section{EXPERIMENTAL RESULTS}

Table.1 Seven day and Twenty eight day compressive strength test results with all the additives

\begin{tabular}{|c|c|c|c|c|c|}
\hline $\begin{array}{c}\text { Types of } \\
\text { concrete cubes }\end{array}$ & $\begin{array}{c}\text { Concrete } \\
\text { with } \\
\text { demolished } \\
\text { concrete(50\% } \\
\text { as CA and m } \\
\text { and (100\%) } \\
\text { as } \begin{array}{c}\text { FA, } \\
\text { without any } \\
\text { additives }\end{array}\end{array}$ & $\begin{array}{l}\text { With } \\
\text { nano silica } \\
\text { (optimum \%) }\end{array}$ & $\begin{array}{l}\text { With } \\
\text { wollastonite } \\
\text { (optimum\%) }\end{array}$ & $\begin{array}{c}\text { With } \\
\text { basalt fibres } \\
\text { (optimum\%) }\end{array}$ & $\begin{array}{c}\text { With all the } \\
\text { three additives } \\
\text { (optimum\%) }\end{array}$ \\
\hline $\begin{array}{c}\text { Seven day } \\
\text { compressive } \\
\text { strength }\end{array}$ & $22.76 \mathrm{MPa}$ & $27.14 \mathrm{MPa}$ & $25.8 \mathrm{MPa}$ & $26.61 \mathrm{MPa}$ & $28.6 \mathrm{MPa}$ \\
\hline $\begin{array}{c}\text { Twenty } \\
\text { eight day } \\
\text { compressive } \\
\text { strength }\end{array}$ & $34.83 \mathrm{Mpa}$ & $41.86 \mathrm{MPa}$ & $40.6 \mathrm{MPa}$ & $42.14 \mathrm{MPa}$ & $43.7 \mathrm{MPa}$ \\
\hline
\end{tabular}

Table.2 Seven day and Twenty eight day compressive strength test results to compute optimum percentage of nano silica

\begin{tabular}{|c|c|c|c|c|c|}
\hline $\begin{array}{c}\text { Types } \\
\text { of concrete } \\
\text { cubes }\end{array}$ & $\begin{array}{c}\text { Concrete } \\
\text { with demolished } \\
\text { concrete(50\%) } \\
\text { as CA and m } \\
\text { sand (100\%) as } \\
\text { FA, without any } \\
\text { additives }\end{array}$ & $\begin{array}{c}\text { With nano } \\
\text { silica (1\%) }\end{array}$ & $\begin{array}{l}\text { With } \\
\text { nano silica } \\
(1.5 \%)\end{array}$ & $\begin{array}{l}\text { With } \\
\text { nano silica } \\
(2 \%)\end{array}$ & $\begin{array}{l}\text { Optimum } \\
\text { of Nano } \\
\text { silica }=1.5 \%\end{array}$ \\
\hline $\begin{array}{c}\text { Seven } \\
\text { day } \\
\text { compressive } \\
\text { strength }\end{array}$ & $22.76 \mathrm{MPa}$ & $24.14 \mathrm{MPa}$ & $27.14 \mathrm{MPa}$ & $25.11 \mathrm{MPa}$ & $27.14 \mathrm{MPa}$ \\
\hline $\begin{array}{c}\text { Twenty } \\
\text { eight day } \\
\text { compressive } \\
\text { strength }\end{array}$ & $34.83 \mathrm{Mpa}$ & $37.14 \mathrm{MPa}$ & $41.86 \mathrm{MPa}$ & $39.61 \mathrm{MPa}$ & $41.86 \mathrm{MPa}$ \\
\hline
\end{tabular}

Table.3 Seven day and Twenty eight day compressive strength test results to compute optimum percentage of wollastonite powder

\begin{tabular}{|c|c|c|c|c|c|}
\hline $\begin{array}{c}\text { Types of } \\
\text { concrete cubes }\end{array}$ & $\begin{array}{c}\text { Concrete } \\
\text { with demolished } \\
\text { concrete(50\%) as } \\
\text { CA and m sand } \\
(100 \%) \text { as FA, } \\
\text { without any } \\
\text { additives }\end{array}$ & $\begin{array}{c}\text { With } \\
\text { wollastonite } \\
(10 \%)\end{array}$ & $\begin{array}{c}\text { With } \\
\text { wollastonite } \\
(15 \%)\end{array}$ & $\begin{array}{c}\text { With } \\
\text { wollastonite } \\
(20 \%)\end{array}$ & $\begin{array}{c}\text { Optimum } \\
\% \text { of } \\
\text { wollastonite } \\
=10 \%\end{array}$ \\
\hline $\begin{array}{c}\text { Seven day } \\
\text { compressive } \\
\text { strength }\end{array}$ & $22.76 \mathrm{MPa}$ & $25.8 \mathrm{MPa}$ & $24.6 \mathrm{MPa}$ & $23.6 \mathrm{MPa}$ & $25.8 \mathrm{MPa}$ \\
$\begin{array}{c}\text { Twenty eight } \\
\text { compressive } \\
\text { strength }\end{array}$ & $34.83 \mathrm{Mpa}$ & $40.6 \mathrm{MPa}$ & $38.8 \mathrm{MPa}$ & $37.6 \mathrm{MPa}$ & $40.6 \mathrm{MPa}$ \\
\hline
\end{tabular}

Table.4 Seven days and Twenty eight days compressive strength test results to compute optimum percentage of basalt fibres

\begin{tabular}{|c|l|c|c|c|c|}
\hline $\begin{array}{c}\text { Types of } \\
\text { concrete cubes }\end{array}$ & $\begin{array}{c}\text { Concrete } \\
\text { with demolished } \\
\text { concrete(50\%) as } \\
\text { CA and m sand } \\
(100 \%) \text { as FA, } \\
\text { without any } \\
\text { additives }\end{array}$ & $\begin{array}{c}\text { With } \\
\text { basalt } \\
\text { fibres } \\
(1 \%)\end{array}$ & $\begin{array}{c}\text { With } \\
\text { basalt fibres } \\
(2 \%)\end{array}$ & $\begin{array}{c}\text { With } \\
\text { basalt fibres } \\
(3 \%)\end{array}$ & $\begin{array}{c}\text { Optimu } \\
\text { m of basalt } \\
\text { fibres = } \\
1 \%\end{array}$ \\
\hline $\begin{array}{c}\text { Seven day } \\
\text { compressive } \\
\text { strength }\end{array}$ & $22.76 \mathrm{MPa}$ & $26.61 \mathrm{MPa}$ & $25.2 \mathrm{MPa}$ & $24.31 \mathrm{MPa}$ & $26.61 \mathrm{MPa}$ \\
\hline $\begin{array}{c}\text { Twenty eight } \\
\text { compressive } \\
\text { strength }\end{array}$ & $34.83 \mathrm{Mpa}$ & $42.14 \mathrm{MPa}$ & $41.2 \mathrm{MPa}$ & $38.8 \mathrm{MPa}$ & $42.14 \mathrm{MPa}$ \\
\hline
\end{tabular}

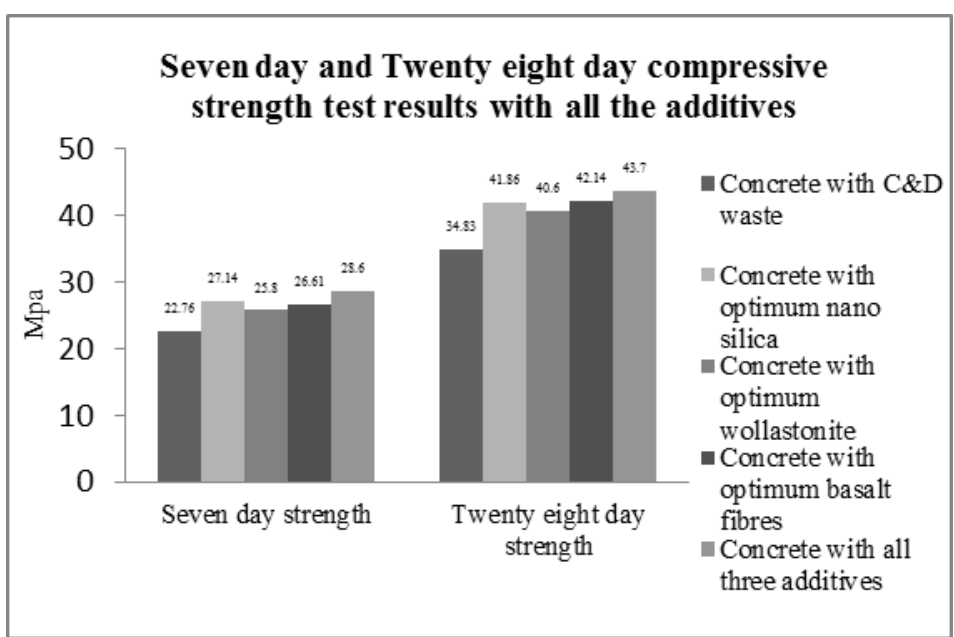

Fig. 1 Comparative strength at optimum dosages of additive mixes

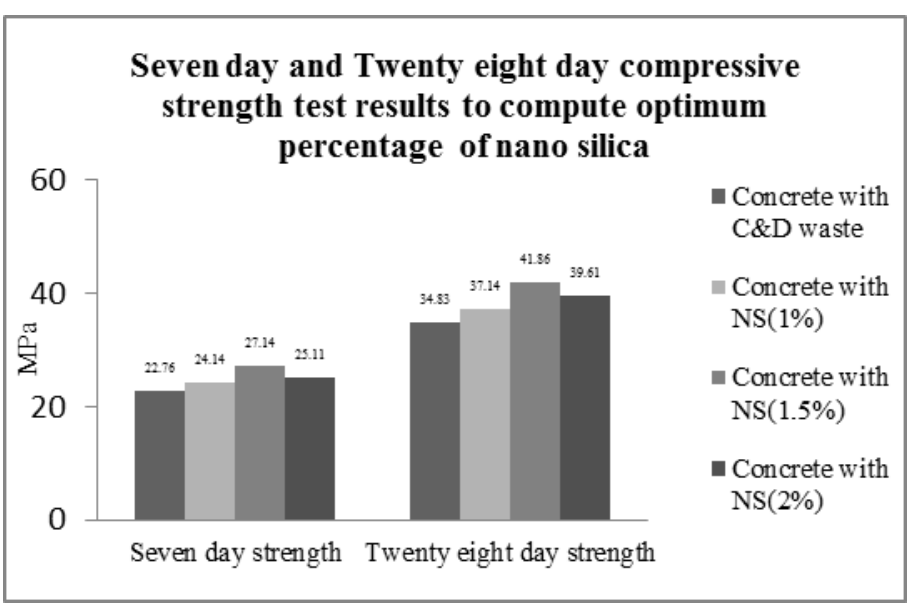

Fig. 2 Comparative strength for different dosages of nano silica

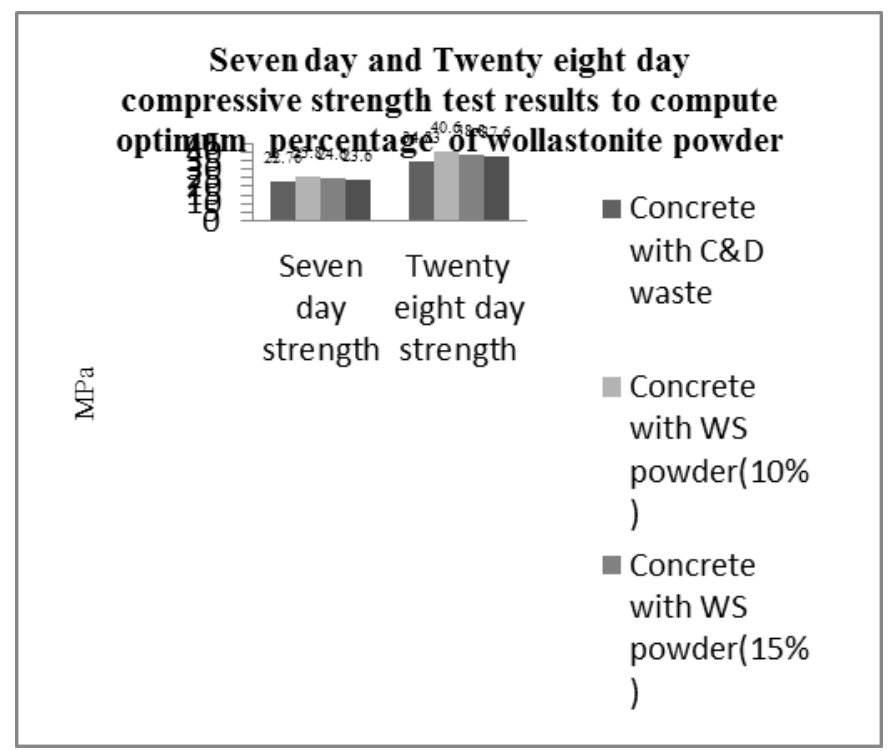

Fig. 3 Comparative strength for different dosages of wollastonite powder 


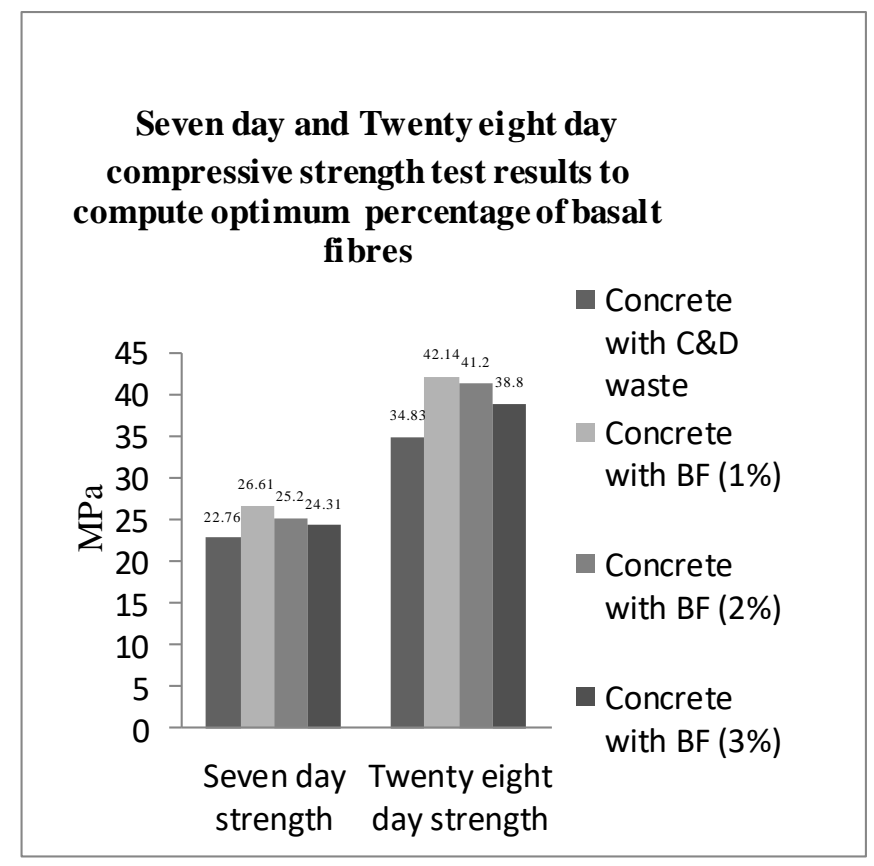

Fig. 4 Comparative strength for different dosages of basalt fibres

\section{CONCLUSIONS}

The following are the conclusions of the work undertaken, and tabulated in Tables 1 to 4 , and shown in Figures 1 to 4 .

1. The 7 day compressive strength without addition of any of the additives is found to be $22.76 \mathrm{Mpa}$.

2 . The addition of the optimum percentages of the additives, increased the 7 day compressive strength to $28.6 \mathrm{Mpa}$.

3 . The 28 day compressive strength without addition of any of the additives is found to be $34.83 \mathrm{Mpa}$.

4. The addition of the optimum percentages of the additives, increased the 28day compressive strength to $43.7 \mathrm{Mpa}$.

5 . Hence, with addition of additives -Nano Silica, Basalt Fibres, and Wollastonite powder, the compressive strength at 7 days and 28 days helps to achieve the desired target compressive strength. The results proves that combination of additives can be added to concrete with C\&D Wastes to regain the compressive strength which is lost due to use of C\&D wastes.

\section{REFERENCES}

[1] Forood Torabian Isfahani, Elena Redaelli, Federica Lollini, Weiwen Li,and Luca Bertolini,"Effects of Nanosilica on Compressive Strength and Durability Properties of Concrete with Different Water to Binder Ratios", Advances in Materials Science and Engineering Volume 2016, Article ID 8453567, $16 \quad$ pages http://dx.doi.org/10.1155/2016/8453567.

[2] Rutuja Mininath Sarade, Suraj Ramesh Shinde, Rohan Kantilal Wayase, Namdev Bapu Rajguru, Dr. P. D. Nemade," Effect of Nano Silica on Compressive Strength of Concrete", IJSRD - International Journal for Scientific Research \& Development| Vol. 5, Issue 04, 2017 | ISSN (online): 2321-0613.

[3] Renu Mathur, A K Misra and Pankaj Goel, "Influence of wollastonite on mechanical properties of concrete", Journal of Scientific \& Industrial Research,Vol. 66, December 2007, pp. 1029-1034.

[4] Kandula Mohankrishna Reddy\& K. V. S. Gopala Krishna Sastry, "Strength properties of concrete using wollastonite-flyash and wollastonite-silica fume", International Journal of Civil, Structural,
Environmental and Infrastructure Engineering Research and Development (IJCSEIERD) ISSN(P): 2249-6866; ISSN(E): 2249-7978 Vol. 6, Issue 5, Oct 2016, pages 1-12.

[5] Tehmina Ayub, Nasir Shafiq, and M. Fadhil Nuruddin,"Effect of Chopped Basalt Fibers on the Mechanical Properties and Microstructure of High Performance Fiber Reinforced Concrete", Hindawi Publishing Corporation, Advances in Materials Science and Engineering Volume 2014, Article ID 587686, 14 pages

[6] Nayan Rathod,, Mukund Gonbare,, Mallikarjun Pujari,,"Basalt Fiber Reinforced Concrete",International Journal of Science and Research (IJSR),2013 ISSN (Online): 2319-7064.

[7] Ahmed, Syed Thouheed, M. Sandhya, and Sharmila Sankar. "A Dynamic MooM Dataset Processing Under TelMED Protocol Design for QoS Improvisation of Telemedicine Environment." Journal of medical systems 43, no. 8 (2019): 257.

[8] Ahmed, Syed Thouheed, M. Sandhya, and Sharmila Sankar. "An Optimized RTSRV Machine Learning Algorithm for Biomedical Signal Transmission and Regeneration for Telemedicine Environment." Procedia Computer Science 152 (2019): 140-149.

[9] Patil, Kiran Kumari, and Syed Thouheed Ahmed. "Digital telemammography services for rural India, software components and design protocol." In 2014 International Conference on Advances in Electronics Computers and Communications, pp. 1-5. IEEE, 2014.

[10] Thouheed, Syed, S. Ahmed, M. Sandhya, and S. Shankar. "ICT's Role in Building and Understanding Indian Telemedicine Environment: A Study." In Information and Communication Technology for Competitive Strategies. Lecture Notes in Networks and Systems, vol 40. Springer Singapore, 2019. 